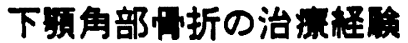

\author{
勝山英明・竹之下廉治・若州实・吉田公哉 \\ 梶岡俊一・安部音八郎・田中陽一・栗山苋二 \\ 川野芳春・岡增一郎
}

\section{Experiences of the treatments for the mandibular angle fracture}

\author{
Hideaki Katsuyama - Yasuharu Takenosita - Minoru Wakamodr \\ Atsuya Yoshida - Shunichi Kajroka - Kihachiro ABE \\ Youichi TANaka - Kanji Kurryama - Yoshiharu Kawano \\ Masuichiro OKA
}

\begin{abstract}
Mandibular fracture treatment occupies a large part of oral surgery in hospital practice, yet much confusion exists in certain basic principles of treatment.

Mandibular angle is known to be one of the most fractured areas in oral surgery because of its configuration and the common fracturing vectors. One big problem exists in dealing with teeth on the fracture line. Some authors consider any fracture through the alveolar socket or the crypt of an impacted tooth as a "complicated" fracture and say that the involved teeth even though uninjured should be extracted promptly because they may be the cause of complications such as nonuion, osteomyelitis, cellulitis or abscess formation. On the other hand, it is suggested that with the use of antibiotics and the application of stable fixation appliances, most clinically intact teeth in the line of mandibular fracture can be retained. From 1978 to MAY 1987, we treated 57 cases of mandibular angle fractures and analyzed the data with special reference to third molar teeth on the fracture line, types of fracture line, and way of approach and treatment.

The majority of cases consisted of males $(51 / 57,89.5 \%)$, and were between 10 and 20 years old (68\%).

Some researchers mentionend that treatment for third molar teeth on the fracture line, but it is rare. So we considered this matter in more details. We, furthermore, examined fracture displacements of fragments, and so on.
\end{abstract}

Key words: mandibular angle fracture, wisdom teeth, surgical treatment

啨言

過去とおいて詳細な記録は残されていないものの、エ

九州大学楼学部口腔外科学第 2 講座

（主任：岡 增一郎数授）

Second Department of Oral Surgery, Faculty of

Dentistry, Kyushu University (Chief: Prof. Masuichiro Oka)

受付日：昭和 63 年 3 月 2 日
トルリフ人が西厏紀元前 600 年位に下頻骨骨折の治㫫に 単額金線結禁 (Mono maxillary gold wiring) を用いた との報告”がある.それから Hippocrates は影に革帯を 用いて直接率引するなど時代の流れと多くの先取者とと るに下頭骨の骨折も進歩を続け現在に至っているわけで ある.

そのなかでも下頻角部は，口腔外科㴭城て大きな割合 を占める下影骨骨折のなかです好発部位の一つとして知

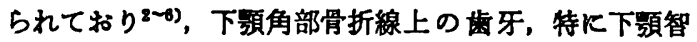
歯の処置に対して数々の報告いはみられるものの詳細な 


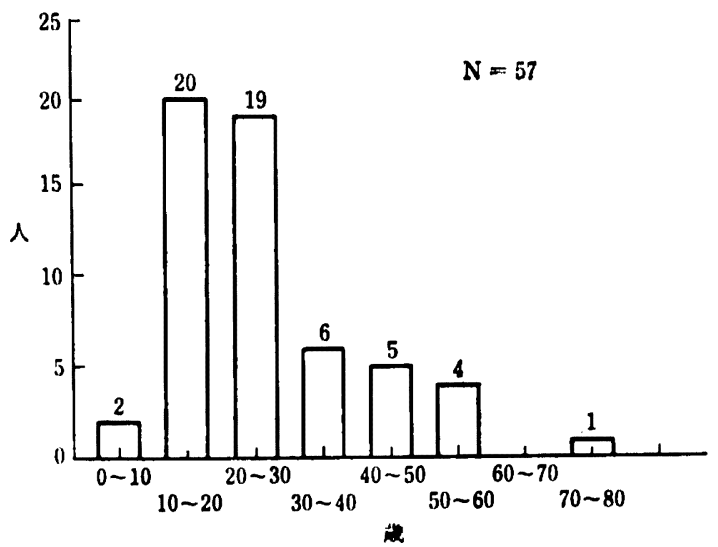

图 1 年路别分布

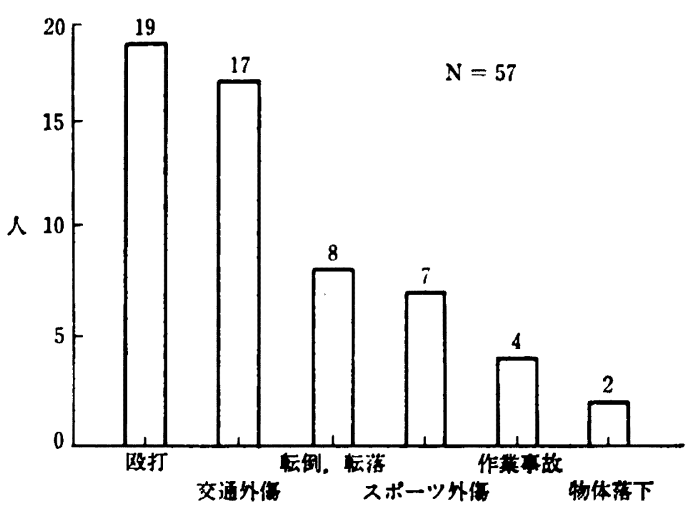

因 2 原因别

報告は少ない，過去飞おいて，骨折線上の埋伏智齿は索 合荤延，または血行障害による感染の原因となりらるこ とから抜齔することを原則にすべき?゙，とい5意見が 大半を占めていたか，より傎重に症例に対処し，齿科的 飞保存の必要性のない智齿の及抜去すべきである。すな わち，骨折線上飞齒牙があるからといらわけではなく， 齿科的に保存可能であるか否か，またその必要性がある 齿牙なのかどらかといらことのほらが重要であるといら 意見) る取近では多くみられるよらКなってきた。過去 において必ず抜去すべきとされていたのが，取近の報告 においては，抜齿操作に上る創部の治象㜊延，炎症症状 の発現などかえって多くの闍題が存在するとの報告いる あり，下額智齔の処圈は今す，多くの検討事項を含んで いるよらである.

過去においては，まず拔去されていた智齿す現在で は，保存可能な場合も多いとの 報告(,9)が増えているの は，Mini-plateなど新しい治㞠法の出現 ${ }^{10-12)}$ により強 固な固定を得られるよらになったといらこと，化学療法 の目ざしい進歩といら背寒をるってのことであるのは

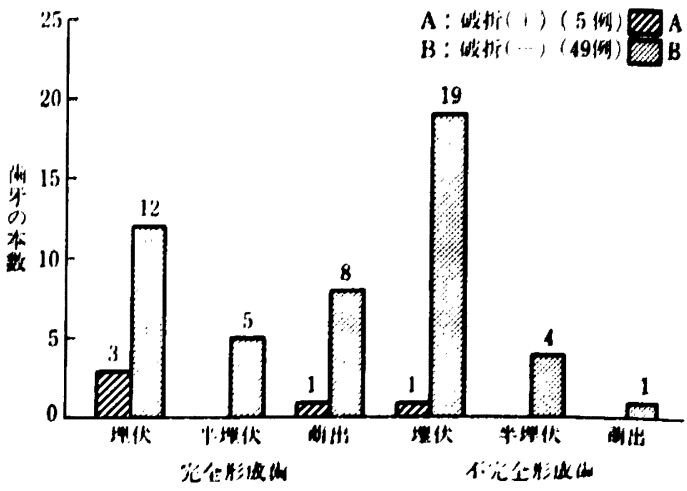

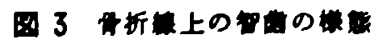

いろまでるない。

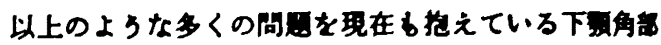
の骨折に対して，われわれは昭和53年より昭和62年5月

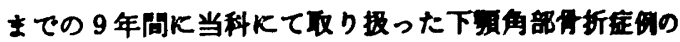
5ち，なんらかの外科如而を加えた57定田K奶して，そ

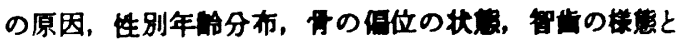
それに対する边是，手街方法，固定期间，お上ひとの成

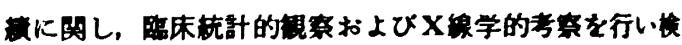
討を加えたので告なる.

\section{效}

対象は1978年から1987年までれわれが汉り报った下 影角部骨折症例のらちなんらかの外科的传量を加えた男 性51例，女性 6 例の計57定例である。

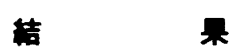

男女比は，8：1で，男住に多かった。年踰別分布は

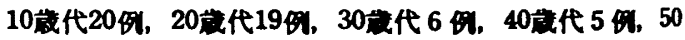

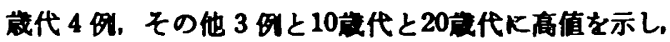
両者で39保，全体の $68.4 \%$ を占めた（园1）. 原因で士

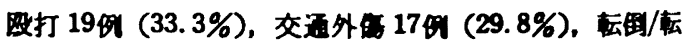

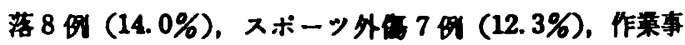
故 4 例 (7\%)，物体落下 2 们（3.5\%）であった（图2）.

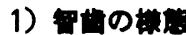

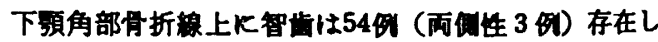

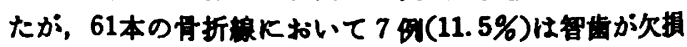

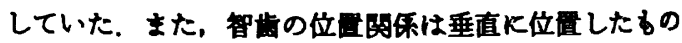
20例(37.0\%)，近心K㑯斜したるの20伊(37.0\%)，遠心 に㑯斜したすの1例 (1.9\%), 水平位位置したるの139 （24.1\%）と遠心に㑯斜したるのが少ない㑯向を示した。 なお完全形成齿は29齿 (53.7\%)て完全埋伏崡15齿 (27.8 $\%)$, 半埋伏齿 5 齿 $(9.3 \%)$, 完全萌出齿 9 齿 $(16.7 \%)$ 


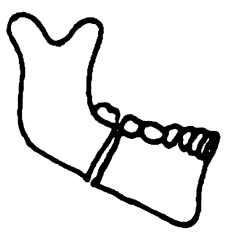

釷 直

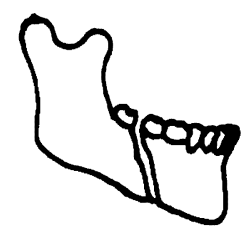

近心方向

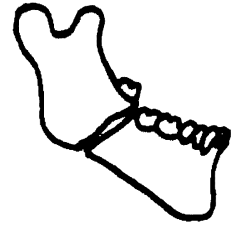

䢖心方向

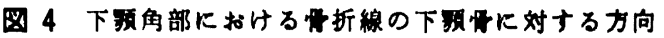

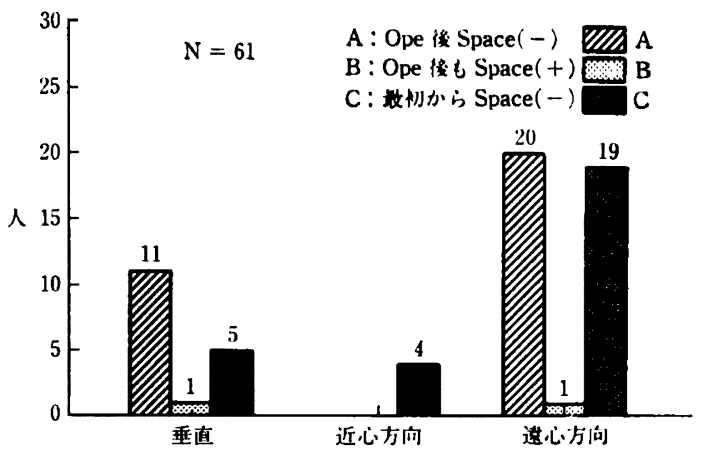

图 5 骨折線の方向

で，5ち完全埋伏齿 3 歯，完全萌出齿 1 歯計 4 歯 $(7.4$ \%) が破折していた，不完全形成齒は25齿 (46.3\%)で, 完全埋伏齿は20齿 (37.0\%), 半埋伏齿は 4 齿 $(7.4 \%)$, 完全萌出齿 1 齿 (1.9\%) で完全埋伏齿 1 齿 $(1.9 \%)$ か

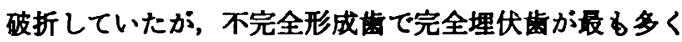
次に完全形成齿て完全埋伏齿が多かった，骨折線上K 存在した智齿 54 例において，埋伏していたるのは 44 齿 （81.5\%）を占めていた（因3）.

\section{2）下額角部に合併した骨折部位}

合併した骨折部位を筋突起部，関節突起部，下䫓上行 使部，骨体部，正中部の 5 つの部位に分けて検索したと ころ, 57 症例中 24 例が下影角部単独飞骨折部位がみら れ，33例において合併した骨折部位がるられた。 その内 訳は, 関節突起部 3 例 $(3 / 33,9.1 \%)$, 骨体部 15 例 (15/ $33 ， 45.5 \%)$ ，正中部15例 $(15 / 33 ， 45.5 \%)$ で，筋突起 部，下頻上行枝部にはみられなかった。

\section{3）骨片の佰位の状复と手街誖の鲆価}

\section{(A) 骨折線の方向}

骨折線の走行方向について垂直方向に走行するるの，

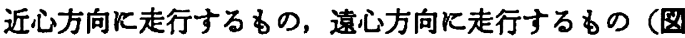
4)の，3通りに分けた．垂直方向に走行していたるの は16例 (26.3\%) で，11例は手術後骨片間のスベースか 消失しており，1 例は手術後るスペースが残存してお り，5例は最初からスペースが存在していなかった。 ま た，近心方向に走行していたものは 4 例で，すべて最初

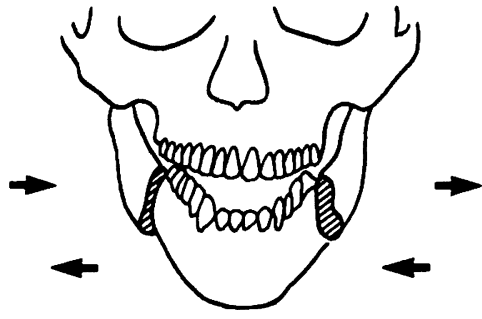

园 6 P-A 方向からみた骨片の傮位

からスペースが存在しないすのであった，遠心方向に走 行していたすのは40例と取多を占め，手術後スペースが 消失したすの 20 例，手術後すスベースが残存したすの 1 例，取初からスベースが存在しなかったすの19例であっ た．以上の上5に手術後スベースが消失したすのと，樶 初からスペースが存在しなかったすのとで59/61 (96.7 \%)と大部分を占めていたことが分かる（因5）.

(B) 骨片の偏位状態

a ） P-A 方向からみた前方骨片の偏位

前方骨片が外側移動したるの，内側移動したるの，偏 位のなかったもの（図6）の3つのタイブK分類した。 外側方移動したすのは22例 (36.1\%) で，17例は手術後 スペースが消失し，4例は手術後すスペースが残存し， 1 例は最初からスペースが存在しないすのであり，前方 骨片が外側移動したものの大部分が後方骨片との間にス ベースを有していたことになる．また，前方骨片が内㑡 に移動したものは19例 (31.1\%) で手衍後スペースが消 失したもの 7 例，取初からスペースが存在しなかったる の12例であり，手術後スベースが牫存したすのはなかっ た，骨片の偏位のみられなかったすのは20例 (32.8\%) で，手術後スベースが消失したすの 4 例，手術後すスべ ースが残存したすの 1 例，最初からスペースが存在し なかったもの15例と骨片の偏位のみられなかったすのの 中では取初からスベースの存在しなかったすのが、3/4 を占めた。 このよらに P-A 方向からみた前方骨片の内 側/外側移動，偏位のないるのの 3 分類に関しては大き な差異はみられなかったか，外側に前方骨片の移動した ものの中で, $1 / 5$ が手衍後す骨片間にスペースが牫り， 


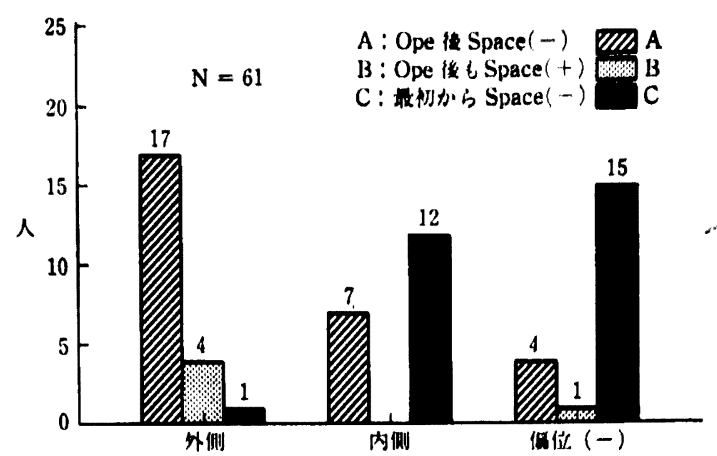

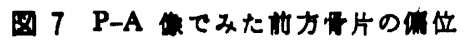

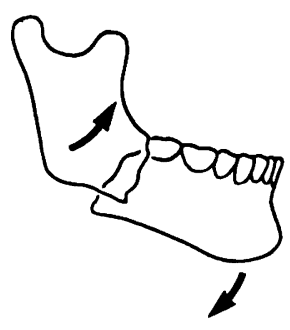

前方骨片下方倡位

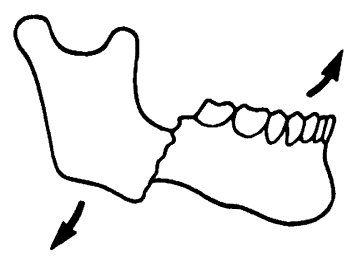

首方骨片上方飞侕位

图8 㑡方からみた骨片の垂直的偏位

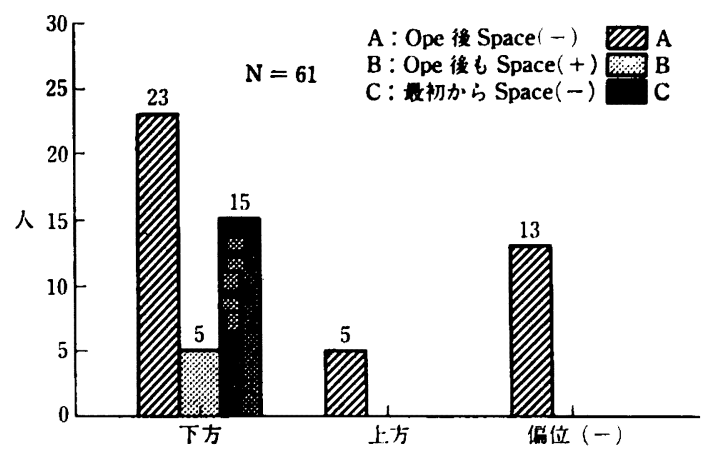

因 9 㑡方覒での前方骨片の垂直的柕位

手術における整復固定が比較的困嚾であることを示昗し

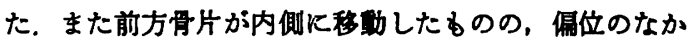
ったるのに関しては最初からスペースがなかったるのが 7/10を占めていた（园7）.

b）侧方からみた骨片の垂直的偏位

側方観上り骨折後の前方骨片の上下的（垂直的）偏位 を钼察した（因 8）が，前方骨片が下方へ移動したるの は43例 (70.5\%) で, 手術後スペースが消失したるの23 例, 手術後すスペースが残存したすの 5 例，最初からス ベースが存在しなかったるの15例であった，前方骨片が

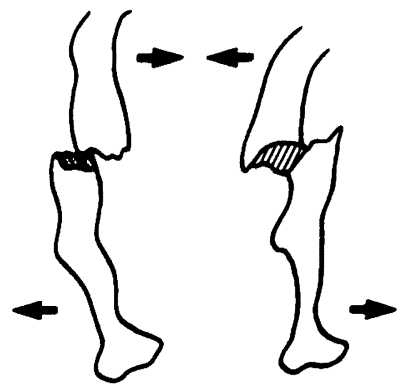

国10 上カからみた片の内外 何への愠位

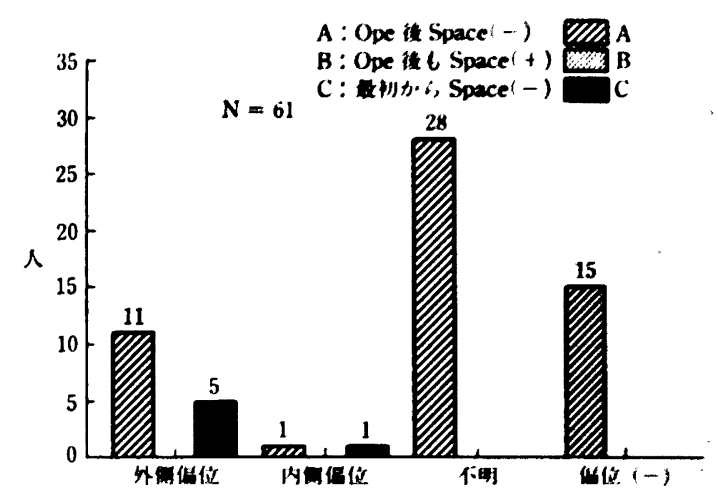

因 11 片の位（方）

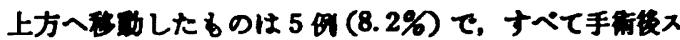
ペースがなくなったbのであった，但位のなかったいの

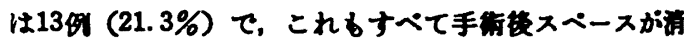
失したるのであった。このデータをみると，尚方骨片が

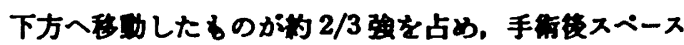

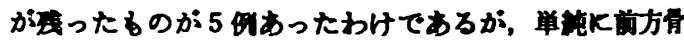

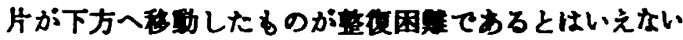
と考えている. 前方片片が上方へ私したいの，但位の なかったるのすへてて手街缕スペースが消失したもので, 整復固定の站果が良好であった（因9）.

\section{c）上方からみた片片の何方但位}

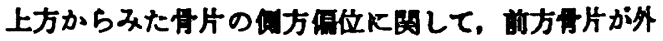

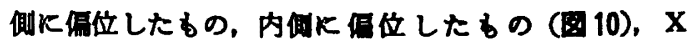
線で不明なるの，但位のなかったるのの，4甬りК分皟 した. 前方骨片が外侧へ但位したるのは16\% (26.2\%)

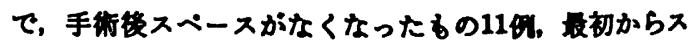
ベースがなかったるの 5 例であった。 内佩へ但位したる のは 2 例 (3.3\%) で1 例は手術後スベースが消失したす の、1 例は段初からスベースが存在しなかったるのであ った. X線で不明なるのは28何 (45.9\%) で，唒位のな かったるのは15例 (24.6\%) であった（图 11). 


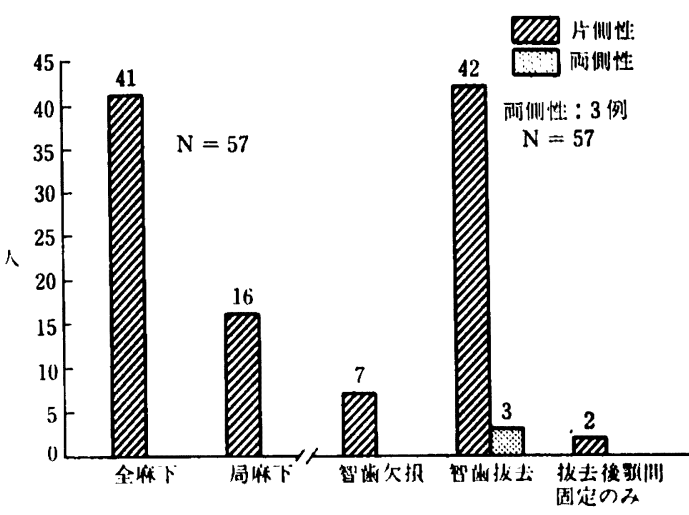

因 12 処显の内容
このよらK, 上方からみた骨片の側方 偏位総数の約 $1 / 2$ をX線で不明なるのが占め，上方から骨片の側方偏 位をX線で判別することは困難な场合が多いことを示唆 したまた外㑡へ偏位したるの16例，内側へ偏位したす の 2 例と 8 倍の值を示し, 外側へ偏位しやすい傾向を示 した，偏位していたすので手術後スペースが浅った症例 はなく，整復固定の困竡な症例はなかった，偏位のあっ たもので手術前にスベースが存在し，手術後スベースが 消失したものは12例 $(66.7 \%)$ と高值を示した.

\section{4）治痖の内容}

57症例中全麻下に行われたるのは 41 例 (41/57，71.9

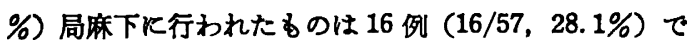
あり，約 2.5 倍全麻下で行われたすのが多かった（図 12). 合計 58 の骨折部位に対して，口腔内のみよりフフ ローチしたすのか34部位 (34/58，58.6\%)，口腔外より

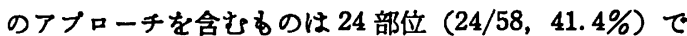
あった，骨折線上の智齿抜去を行ったものは 45 例 (45/ $54 ， 83.3 \%) ， 5$ ち両僋性 3 例，技去後額間固定を行っ たものは 2 例 (4.4\%) と智歯が存在するすのは当科に おいては積極的に抜去された（図 12）．智雪拔去例45例 中抜去後骨䉽合を行ったるのは31例(31/45，68.8\%)で, 口腔内より骨揵合を行ったるのは 18 例 (18/31，58.1 \%)，口腔外上り骨䋖合を行ったるのは 13 例 (13/31, 41.9\%）で口腔内より骨拜合を行ったるのが多かった。

骨揵合に関して当科では Hayton-Williams 法結禁, 十字型結䇣, V字型結禁の 3 通りを行っているが，頻度 的仙 Hayton-Williams 法結禁, 十字型結禁, V字型 結禁の順であった。

顕間固定の期間に関しては57症例中不明が 1 例で, 固 定しなかったもの 1 例 $(1 / 56,1.8 \%) ， 2$ 週間以内のも の11例 $(11 / 56,19.6 \%), 2$ 週より長く 3 週間以内のむ の 6 例 $(6 / 56,10.7 \%), 3$ 週上り長く 4 週間以内のもの 32 例 $(32 / 56,57.1 \%) ， 4$ 週より長く 5 週間以内のもの 0 例, 5 週上り長く 6 週間以内の 6 の 6 例 $(6 / 56,10.7$
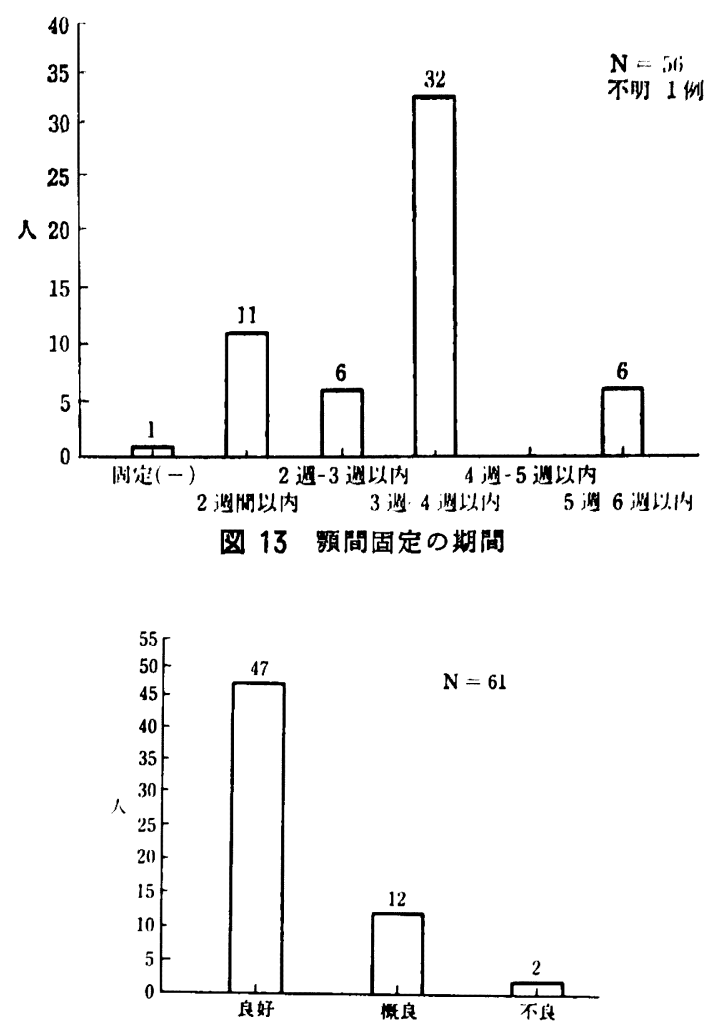

因 14 手術による整復の評価

\%)で 3 週より長く 4 週間以内のものがもっとも多く約 6 割を占め，次に 2 週间以内のるのが多く約 2 制を占め た（図 13）.

5）第了骨片の有無と手術による整復の枰価

57应例，61の骨折部位において第 3 骨片がないるの 52 部位 $(52 / 61 ， 85.2 \%)$ ，第 3 骨片があったもの 9 部位 $(9 / 61 ， 14.8 \%)$ と第 3 骨片があったものが約 6 倍あっ た.

整復の評価に対し，整復良のもの，概良のるの，不良 のすのの 3 通りに分けたところ，良好：47例 (47/61， $77.0 \%)$, 概良：12例 $(12 / 61,19.7 \%)$ ，不良：2 例(2/ $61 ， 3.2 \%$ ）と大部分の症例保良好な整復を得ることが でき，不良はなかった（図 14）。

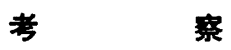

下䫑骨骨折㤌古代の昔からみられたるのの，近年の著 しい交通㡏送機関の進歩，特飞過去数年のシートベルト 着用義務化により，骨折の様態および治寮法にすかなり 変化がみられている。 下䫓骨骨折の治療には従来よりの 観血的整復固定と，額間固定のみを用いる非観血的整復 
固定などが用いられているが，ワイヤーによる䋖合が 主流を占めていた時代から A-O plate, Champy ${ }^{10,13)}$ の mini-plate などの登场により大をな殂草を遂げてを

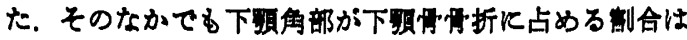

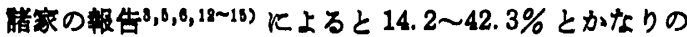

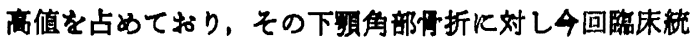
計的钼察を行ったわけであるが，先に速べたよらに対象

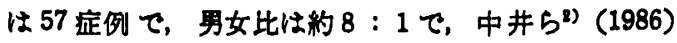

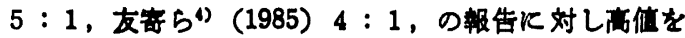
示したものの, 男性に多いといら点では盖具はみられな

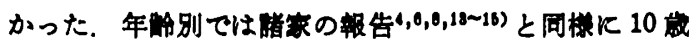

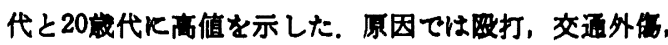

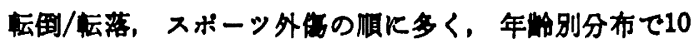

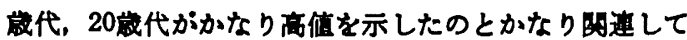

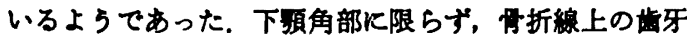

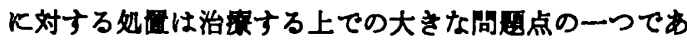
るか，骨折線上の齿牙対する考方方近年大きく变わ り，過去飞おいては骨折線上の歯牙は篦合㜊延，感染の原 因になるとしてすべて拔去すべきである゙,もとされてい たのに対し，治暴法の進歩により强力な額間固定が得ら れるよらになったことや，化学暴法威の進歩などKより，

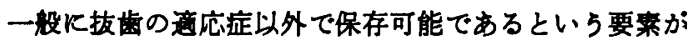
みいだせる場合は保存すべきであるといら意見(99 飞落 ち着いてきているよらであるが，そらいら状況におい

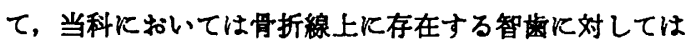

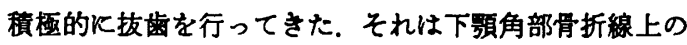
智齒は保存する利益よりる拔齿し，感染などの合併症か ら患者を守ろらとするゆえんである。当科が経験した 57 症例では，不完全形成完全埋伏であったすのがす 多く智歯全体の $37.7 \%$ 占め，次浣全形成齿で完全埋 伏のものが多く，28.3\%を占め，埋伏齔は骨折線上の智 歯全体の約 $84 \%$ を占めており，萌出方向に注目すると， 垂直に位置したるのは37.0\%で約 2/3 が近心，遗心，水平 方向位值しており，保存する利益が少ないと考えられ たものが多かった。当科吅いては57症例中41例を全麻 下K行ってょり，患者の負担を少なくするために骨の整 復固定の手術時何同時飞智齿を技去した例が多かった。

しかし，骨折線上の齿牙が骨片をロックした状的で，骨 片の偏位を少なく留めている場合などすあり，固定前に それらの崡牙を抜去することは整復固定を困難にする场 合すあり，そらいら症例においては抜去するにしてす固 定後拔去するよらにした症例すあった。るちろん他の部 位の骨折線上の齿牙て崡科的保存する利益のあると思 われる齿牙に対しては極力保存する体制をとっている。

下頻骨角部の骨折の治療において大きな役割を果たして いるすののひとつに mini-plate があるが, Champy10,11) は, Michelet ${ }^{12)}$ (1973) の下顥骨の骨接合術をアレンシ して mono-cortical と圧力を加えず， mini-plate を用い た固定法により頻間固定は必要でないと主張した。彼

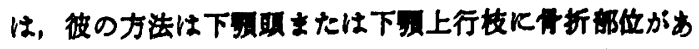

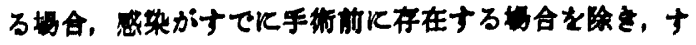

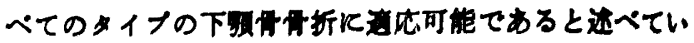
る. その利点として (1) 不必受な scarを作ることなく approach がンンプルである (2) 合併庭がそれまでの衙

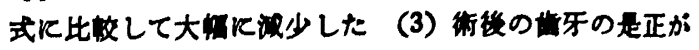

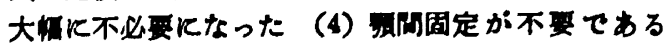

（5）不快忽の成少などの利点をあけていいが，(5) の不

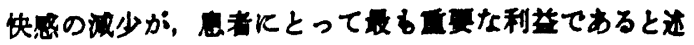
ペている.

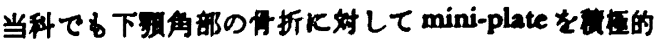
К用いているか，前述のよろに Champy は可周图定は

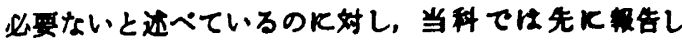

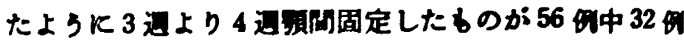

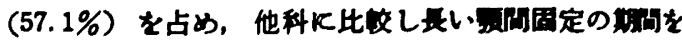
啟定している。これは plate Kよる固定のみでなくさら

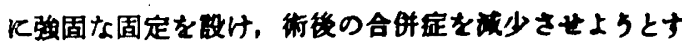

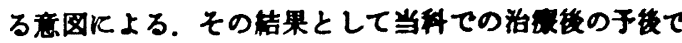
なんらかの合垪症がみられたるのは61肿 2 代 (3.3\%) で，成維としては良好であったと考えているか，期間固 定の期間の短樎は患者にとって曼大の和益の一つであ

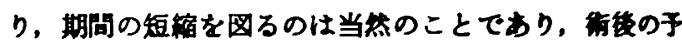
後とのバランスがとれればできるだけ短くなるよらに努 カすへきと考えている. 願間固定の期间て取る多かった のは3〜4週といらデータがでていたが mini-plateが 入されてからの統計を求めるとかなり短くなるであろ 5. mini-plate の学入Kより影间固定の期间が短くなっ

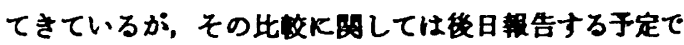
ある.

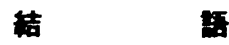

今回われわれは，九州大学齿学部第 2 口些外科学数室 Кおいて昭和53年より昭和62年までの 9 年間になんらか

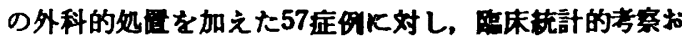
よびX線学的考察を行ったので謄告した。

1. 男女比は約 $8: 1$ で, 男性に多く，10咸代と 20咸 代で全体の $68.4 \%$ を占めた. 原因では渡打 (33.3\%),

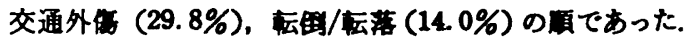

2. 角部骨折線上に存在した智齿は不完全形成齿で, 完全埋伏のるのが最す多く(37.0\%), 次完全形成齿 で完全埋伏のるのが多かった (27.8\%).

3. 骨折線の方向は遗心㮌斜したるのが多く全体 の約 2/3 を占めた。

4. 側方からみた书片の垂直的㣂位は前方骨片が下方 に移動したるのが最す多く，全体の約 $2 / 3$ を占めた.

5. P-A 方向からみた骨片の倡位関しては内側に移 動したるの，外側に移動したるの，婂位のなかったるの て大きな差はなかった。 


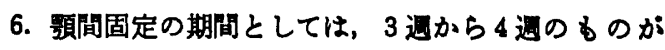
取も多かった.

本㻅文の要旨は第32回日本口貯外科学会総会（杗京） において発表した。

\section{引 用 文 献}

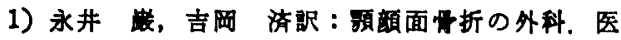
莱菜出肘, 12-31 1968.

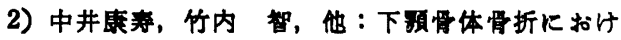

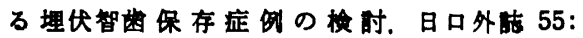
449-454 1986.

3）西原茂昭，長谷川幸一，他：過去15年凬の当教

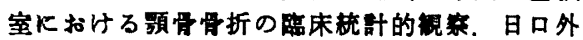
誌 26: 726-733 1980.

4）友寄英基, 久保四郎, 他：下䫓角部骨折 126 症

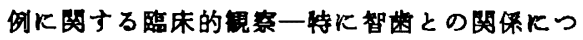
いて一. 日外誌 31: 34-40 1985.

5) Kelly, D.E. and Harrigan, W.F.: A Survey of facial fractures: Bellevue Hospital 19481974. J Oral Surg 33: 146-149 1975.

6）寺井陽店，小野克己，他：下额骨骨折 138 症例 K関する臨床的检討。日外誌 31：2776-2785 1986.

7) Thoma, K.H.: Oral Surgery. Mosby Co, St Louis, 1969, p 437-618.

8）小浜源郁，古田愁，他：下预骨骨折 317 症例

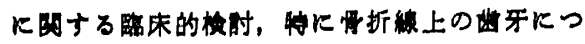
いて。 日外伎 23: 237-242 1977.

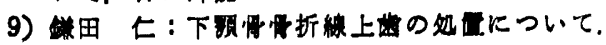
日外洁 29: 1718-1729 1983.

10) Champy, M., Lodde, J.P., et al.: Plattenosteosynthesen bei Mittelgesichtsfrakturen und -osteotomien: Dtsch. Z. Mund-Kiefer-GesichtsChir. 2: 26-29 1978.

11) Champy, M., Lodde, J.P., et al.: Mandibular Osteosynthesis by Miniature Screwed Plates Via a Buccal Approach. J Max-Fac Surg 6: 14-21 1978.

12) Michelet, F.X., Deymes, B.D., et al.: Osteosynthesis with minituarized screwed plates in maxillo-facial surgery. J Mac-Fac Surg 1: 791973.

13) Goldberg, M.G. and Williams, A.C.: The location and occurence of mandibular fractures. OS. OM. OP. 28: 336-341 1969.

14）高井功羓, 赤井元芳, 他：過去 3 か年に打ける

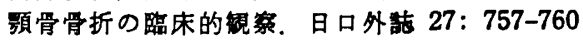
1981.

15）增村典子，高橋良夫，他：下穎骨骨折の臨床梳

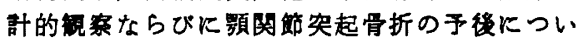
て。 日外誌 28: 2028-2035 1982.

16）乙贯典子，朝合昭人，他：独㙝医科大学口貯外 科火求ける過去 6 年间の頻骨骨折の䠛床赫計的 㘥察。 日外誌 28: 1551-1559 1982. 